УДК 159.9:376.37:053.66

https://doi.org/10.52058/2708-7530-2021-12(18)-505-513

Харченко Тамара Григорова кандидат психологічних наук, викладач кафедри логопедії, Сумський державний педагогічний університет імені А.С. Макаренка, вул. Роменська, 87, м. Суми, 40002, тел.: (0542) 68-59-02, e-mail: kharchenko88@gmail.com ${ }_{2}$ https://orcid.org/0000-0002-4239-3434

Щербакова Ірина Миколаївна доцент, кандидат філософських наук, доцент кафедри психології, Сумський державний педагогічний університет імені А.С. Макаренка, вул. Роменська, 87, м. Суми, 40002, тел.: (0542) 68-59-02, e-mail: ishcherbakova@ukr.net, https://orcid.org/0000-0001-5900-5189

Шарпило Олена Володимирівна здобувач II курсу другого (магістерського) рівня, Сумський державний педагогічний університет імені А.С. Макаренка, вул. Роменська, 87, м. Суми, 40002, тел.: (0542) 68-59-02, e-mail: helen_po@ukr.net

\title{
СПЕЦИФІЧНІ СИМПТОМИ ДЕЗАДАПТИВНОЇ ПОВЕДІНКИ ДІТЕЙ МОЛОДШОГО ШКІЛЬНОГО ВІКУ ІЗ ПОРУШЕННЯМИ МОВЛЕННЯ
}

Анотація. У статті подано результати теоретичного й емпіричного дослідження специфічних симптомів дезадаптивної поведінки дітей молодшого шкільного віку із порушеннями мовлення. На основі теоретичного аналізу досліджуваної проблеми визначено, що поведінка дітей молодшого шкільного віку із мовленнєвими порушеннями, $\epsilon$ сукупністю дій і вчинків, а тому ії доцільно досліджувати як намір дитини робити, або не робити будь що. 3'ясовано, що найбільш розповсюдженими порушеннями у поведінці дітей молодшого шкільного віку із порушеннями мовлення є схильність робити все навпаки, ігнорувати або чинити опір дорослим, упертість, непокірність, неслухняність, самовілля, агресивно-бунтівна поведінка, схильність до сварок, категоричність думок й висловлювань, схильність ображати старших. Визначено, що мовленнєві порушення обумовлюють специфічний характер спілкування й поведінки дітей із порушеннями мовлення, зокрема низький рівень мовленнєвої активності дезорієнтує дітей в ситуації спілкування.

Емпіричне дослідження особливостей поведінки дітей молодшого шкільного віку із порушеннями мовлення проведене за згоди батьків дітей, за допомогою трьох психодіагностичних методик (опитувальник «Діагностика i критерії оцінювання неконструктивної поведінки дітей»; анкета «Агресивність, гіперактивність i комунікативна толерантність» В. В. Бойко; тест

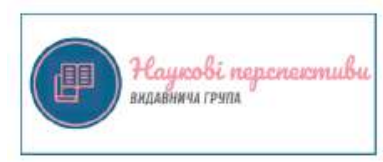


«Тривожність» Р. Темл, М. Доркі, В. Амен). Дослідження дозволило визначити, що залежно від рівня комунікативних порушень дітей молодшого шкільного віку із порушеннями мовлення можна поділити на типологічні групи: діти 3 нульовим ступенем фіксації на порушенні; діти iз труднощами у процесі встановлення контакту з іншими людьми; діти із постійною фіксацією на своїх мовленнєвих невдачах. Встановлено, що специфічними симптомами дезадаптивної поведінки дітей із порушеннями мовлення $\epsilon$ надмірна агресивність, активність, упертість, емоційна неврівноваженість, конфліктність.

Ключові слова: поведінка, дезадаптивна поведінка, порушення мовлення, неврівноваженість, агресивність, неслухняність.

Kharchenko Tamara Grigorovna Candidate of psychological sciences, lecturer of the department of logopedy Sumy State A. S. Makarenko Pedagogical University, Romenska St., 87, Sumy, 40002, tel.: (0542) 68-59-02, e-mail: kharchenko88@gmail.com,https://orcid.org/0000-0002-4239-3434

Shcherbakova Iryna Nikolaevna Candidate of philosophical sciences, associate professor at the department of psychology Sumy State A. S. Makarenko Pedagogical University, Romenska St., 87, Sumy, 40002, tel.: (0542) 68-59-02, e-mail: ishcherbakova@ukr.net, https://orcid.org/0000-0001-5900-5189

Sharpylo Olena Volodymyrivna Student of the second (master's) level of the Sumy State A. S. Makarenko Pedagogical University, Romenska St., 87, Sumy, 40002, tel.: (0542) 68-59-02, e-mail: helen_po@ukr.net

\title{
SPECIFIC SYMPTOMS OF MALADAPTIVE BEHAVIOR OF CHILDREN OF PRIMARY SCHOOL AGE WITH SPEECH DISORDERS
}

\begin{abstract}
The paper presents the results of a theoretical and empirical study of specific symptoms of maladaptive behaviour of primary-school-age children with speech disorders. Based on the theoretical analysis of the problem studied, it is determined that the behaviour of children of primary school age with speech disorders is a set of actions and deeds, so it is advisable to investigate it as the child's intention to do, or not do anything. It is found out that the most widespread behavioural problems of children of younger school age with speech disorders are the tendency to do everything another way around, to ignore or resist adults, obstinacy, indocility, disobedience, arbitrariness, aggressive and rebellious behaviour, a propensity for dumps, tendency to offend seniors and even to spoil things, to break toys, despotism (as an extreme arbitrariness). It is determined that speech disorders cause a specificity of communication and behaviour of children with speech disorders, among other things a low level of speech activity disorientates children in a
\end{abstract}


communicative situation.

Empirical research of behaviour features of primary-school-age children with speech disorders conducted with parental consent, using three psychodiagnostic methods (the questionnaire «Diagnosis and criteria for assessing non-constructive behaviour of children»; «Aggressiveness, hyperactivity and communicative tolerance» survey by V. V. Boiko, «Anxiety» test (R. Teml, M. Dorki, V. Amen)) made it possible to determine that depending on the level of communicative disorders, children of primary school age with speech disorders can be divisible into typological groups: children with zero degrees of fixation in violation; children with difficulties in contacting others; children with a constant speech failures fixation. It is deemed that the specific symptoms of maladaptive behaviour of children with speech disorders are excessive aggressiveness, activity, stubbornness, emotional imbalance, proneness to conflict.

Keywords: behaviour, maladaptive behaviour, speech disorder, unbalance, aggressiveness, disobedience.

Постановка проблеми. Важливість дослідження поведінки дітей молодшого шкільного віку із мовленнєвими порушеннями на етапі вступу до закладів освіти не викликає сумніві, адже саме під час перших років навчання молодший школяр здобуває психологічний досвід, який на фоні появи багатьох вікових новоутворень цього важливого періоду у житті дитини, визначає характер особистісного розвитку наступних вікових періодів.

Дослідники наголошують, що проблема дезадаптації найгостріше заявляє про себе саме в молодшому шкільному віці, коли до чинників, що обумовлюють труднощі онтогенетичного розвитку, приєднується соціальнопсихологічна дезадаптація школяра [2]. Вважаємо, що найважливішою причиною дезадаптації молодших школярів із мовленнєвими порушеннями $\epsilon$ властивості особистості дитини, зокрема мовленнєві порушення, які обумовлюють появу дезадаптивних форм поведінки. Саме тому, важливість й складність аналізу специфічних симптомів дезадаптивної поведінки дітей молодшого шкільного віку із порушеннями мовлення, полягає не стільки у визначенні відповідності таких поведінкових проявів нормативним критеріям, скільки в тому, наскільки дії дитини відповідають «нормі» у розумінні самої дитини [6].

Отже, вважаємо дослідження специфічних симптомів дезадаптивної поведінки дітей молодшого шкільного віку із порушеннями мовлення актуальним предметом теоретичних й емпіричних досліджень.

Аналіз останніх досліджень і публікацій. Дослідженням дезадаптивної поведінки дітей молодшого шкільного віку із порушеннями мовлення займались провідні вітчизняні й закордонні науковці. Серед закордонних дослідників, які займаються дослідженням дітей 3 негативними проявами поведінки, а також вивчають фактори, які обумовлюють цю поведінку, слід 
відзначити Dwyer Kevin, Meme Hieneman, Mike Nolan, Judy Presley, Lynn De Turo, Winnie Gayler, Glen Dunlap. Серед вітчизняних науковців на увагу заслуговують праці Бісікало Л.Г., Грибова О.Е, Жук Т.В., Ілляшенко Т.Д., Кардаш Н.О., Каменщук Т.Д., Коцан І.Я., Осауленко Л.А., Паламарчук Н.М., Рібцун Ю., Якимчук Г.В. та ін.

Мета статті - теоретичне обгрунтування й емпіричне вивчення особливостей дезадаптивної поведінки дітей молодшого шкільного віку із порушеннями мовлення.

Виклад основного матеріалу. Науковці стверджують, що діти 3 дезадаптованою поведінкою - це діти із порушеним ставленням до норм поведінки. На думку Ніколаєв Л. О., Маркелова А. В, ініціація дезадаптації відбувається за участю різних чинників, які можна об'єднати в дві основні групи: зовнішню (соціальні, або об’єктивні чинники), та індивідну (особистісні, або суб'єктивні чинники) [2, с. 126]. Посилаючись на Осауленко Л. А., можна стверджувати, що у дітей молодшого шкільного віку із порушеннями мовлення за несприятливих умов життя й неправильного виховання, 3'являються й закріплюються такі небажані і несхвальні прояви поведінки, як агресивність, жорстокість, байдужість, жадібність, брехливість [3, с. 45].

У нашому дослідженні, ми розглядаємо поведінку як дієву форму вчинкової активності людини, характер якої визначається наявністю або відсутність наміру діяти певним чином та актуальним потребово-мотиваційним станом особистості. Визначаючи специфічні симптоми дезадаптивної поведінки дітей молодшого шкільного віку із порушеннями мовлення, вважаємо що критерієм аналізу має бути наявність або відсутність у дитини наміру робити ту чи іншу дію, або не робити будь що взагалі [6, с. 405-406]. Дезадаптивну поведінку ми розглядаємо, як сукупність неадекватних, погано контрольованих, конфліктних вчинків дитини, як неадекватні способи поведінки, які суперечать існуючим нормам й очікуванням інших.

Рібцун Ю. В. звертає увагу на такі особливості дітей молодшого шкільного віку із порушеннями мовлення: обмеженість вербальних засобів спілкування; емоційна нестійкість; слабкість мотиваційної основи діяльності; слабкий вольовий самоконтроль; фрагментарність сприймання інформації; моторна незграбність; недосконалість мисленнєвих операцій; дефіцит уваги до оформлення мовлення; недостатній словниковий запас; незрілість навичок мовленнєвого спілкування [4, с. 140]. Симптомами дезадаптивної поведінки дітей молодшого шкільного віку із порушеннями мовлення $\epsilon$ : агресія по відношенню до людей і речей, надмірна активність, постійне фантазування, упертість, систематичні емоційні розлади, почуття власної неповноцінності, неадекватні фобії, підвищена збудливість i конфліктність, нездатність зосереджуватись на роботі, невпевненість у прийнятті рішень, неправдивість, надмірна похмурість і незадоволеність, завищена самооцінка, постійні втечі зі школи та дому, смоктання пальців, гризіння нігтів, енурез, тремор рук і ніг [1]. 
Фірсанова О. Ю. звертає увагу на наявність двох типів конфліктної поведінки у дітей молодшого шкільного віку із порушеннями мовлення: 1) агресивної (спрямованої на ініціацію конфлікту); 2) демонстративної (спрямованої на привернення уваги). Дослідниця також визначає наявність двох типів пасивної поведінки: 1) зовнішньо-внутрішнього підпорядкування; 2) зовнішнього підпорядкування вимогам [5]. При переході до шкільного віку у дітей молодшого шкільного віку із порушеннями мовлення можуть спостерігатись наступні прояви негативної поведінки: прагнення робити все навпаки; надмірна упертість, яка проявляється як бажання досягти бажаного у будь-який спосіб; схильність до непокірності; самовілля; деспотизм [3, с. 45].

Враховуючи наведене вище, зазначимо, що залежно від типу агресії який прослідковується у поведінкових реакція дітей молодшого шкільного віку із порушеннями мовлення, науковці поділяють таких дітей на п'ять типів: гіперактивно-агресивних (рухливо-розгальмованих); агресивно-вразливих; агресивно-боязких; агресивно-байдужих; дітей 3 опозиційно-зухвалою поведінкою (грубіянять дорослим) [3, с. 50].

Вважаємо за необхідне наголосити, що аналіз конкретних форм прояву небажаних поведінкових реакцій дітей молодшого шкільного віку із мовленнєвими порушеннями доцільно проводити через визначення провідного стилю поведінки дитини, а також з'ясування досвіду дитинства, який дорівнює сумі емоційного досвіду спілкування та емоційного досвіду виконання діяльності, який дитина здобула. Щербакова I. М., Харченко Т. Г. визначили критеріями факторного аналізу поведінки таких дітей: 1) проактивність / реактивність поведінки; 2) орієнтацією «на інших / від інших / проти інших (дозволить 3'ясувати поступливою, відокремленою або ворожою є поведінка дитини із мовленнєвими порушеннями); 3) рівень самооцінювання (самооцінка залежна, агресивна, упевнена). Аналізуючи поведінку дитини молодшого шкільного віку із мовленнєвими порушеннями необхідно з'ясувати: 1) схильність дитини до конфліктної поведінки; 2) тип конфліктної поведінки: агресивний (ініціація конфліктів) або демонстративний (привернення уваги); характер конфліктної поведінки: пасивний (як зовнішньо-внутрішнє підпорядкування на фоні заниженої самооцінки); активний (як зовнішнє підпорядкування на фоні афективних спалахів) [6, с. 407].

3 метою дослідження специфічних симптомів дезадаптивної поведінки дітей молодшого шкільного віку із порушеннями мовлення нами було проведено емпіричне дослідження першокласників із ротацизмом (43\%), парасигматизмом (43\%), невротичною заїкуватістю (14\%). Дослідження проведено за допомогою трьох методик: опитувальника «Діагностика і критерії оцінювання неконструктивної поведінки дітей»; анкети «Агресивність, гіперактивність і комунікативна толерантність» В. В. Бойко; тесту «Тривожність» Р. Темл, М. Доркі, В. Амен. 3 метою визначення ознак неконструктивної поведінки (їх наявності, або відсутності) у дітей- 
респондентів, нами було проведено опитування батьків. За допомогою опитувальника «Діагностика і критерії оцінювання неконструктивної поведінки дітей» ми визначили типи неконструктивної поведінки дітей-респондентів. Встановлено характерні для респондентів форми неконструктивної поведінки, а саме: для 14\% респондентів характерна конформна поведінка, у 29\% дітей домінує конформно-агресивна поведінка, 43\% респондентів проявляють агресивну поведінку, 14\% вдаються до відкритої протестної поведінки (див. рис.1.).

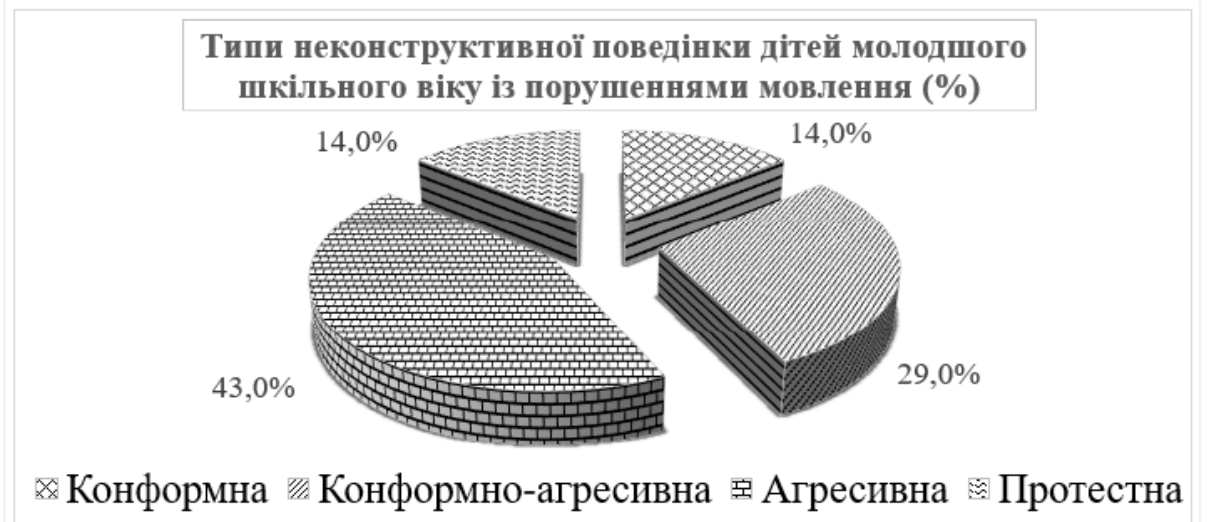

Рис. 1. Типи неконструктивної поведінки дітей молодшого шкільного віку із порушеннями мовлення (\%).

3'ясувавши частоту, тривалість, ступінь і ситуаційну специфічність форм неконструктивної поведінки респондентів й підрахувавши сумарний бал за вказаними критеріями, ми визначили дітей, які потребують психологопедагогічної допомоги, а саме 57\% опитаних потребують термінової кваліфікованої психолого-педагогічної допомоги; 43\% респондентів потрапили до «групи ризику», це діти, які потребують корекційної роботи.

Рівень комунікативної толерантності, агресивності та гіперактивності респондентів ми визначили за допомогою анкети «Агресивність, гіперактивність і комунікативна толерантність» В. В. Бойко. Встановлено, що 57\% респондентів мають середній рівень комунікативної толерантності, 43\% опитаних мають високий рівень комунікативної толерантності (див. рис. 2).

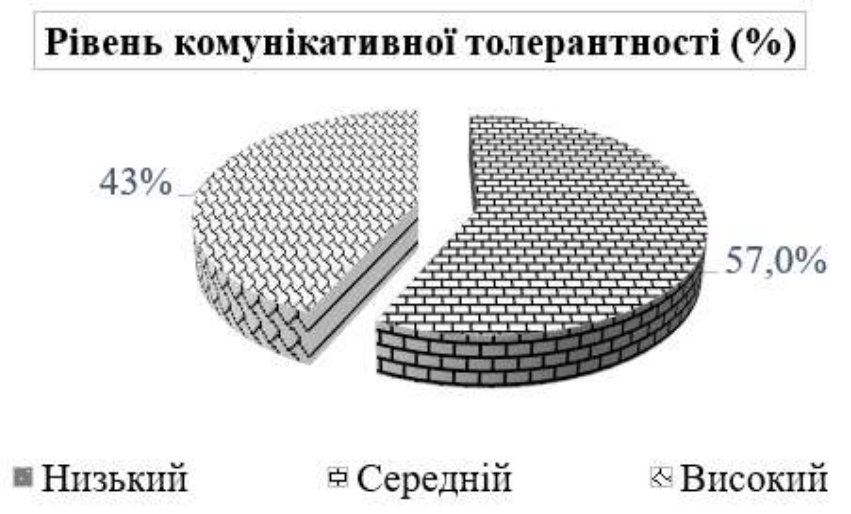

Рис. 2. Рівень комунікативної толерантності респондентів (\%). 
3'ясовано, що серед респондентів відсутні прояви субнормальної, гіпертрофованої й брутальної агресії. Визначено, що 100\% респондентів мають середній рівень прояву агресивної поведінки. Встановлено, що нормальна агресивність характерна для $29 \%$ респондентів, а помірно-захисна агресивність спостерігається у $71 \%$ опитаних. Отже, переважна більшість дітей вдається до проявів помірно-захисної агресивності (див. рис. 3).

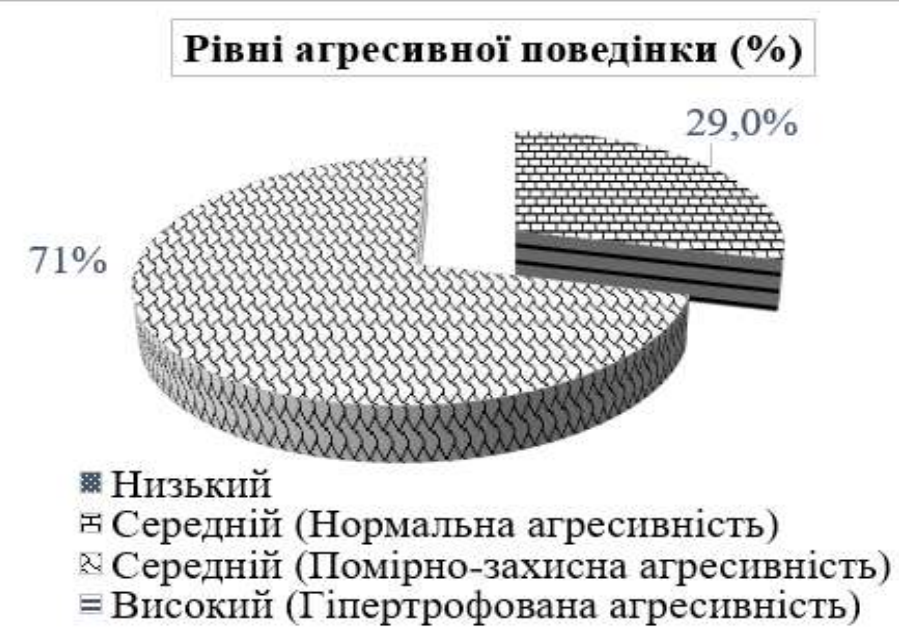

Pис. 3. Рівні агресивної поведінки респондентів (\%).

3 метою визначення рівня тривожності дітей, ми провели дослідження за допомогою проективної методики «Тривожність» (Р. Темл, М. Доркі, В. Амен), яку використали враховуючи що вік респондентів становить 6-6,5 років. Кожну дитину ми просили уважно подивитися на картинку (показували картинки по черзі у встановленому порядку) й підібрати для дитини обличчя (сумне або веселе). Ми фіксували кількість виборів, їх якість.

Кількісний аналіз отриманих результатів дозволив визначити по-перше, що серед респондентів відсутні діти із низьким рівнем тривожності, а по-друге, що низький рівень IT (індекс тривожності) також відсутній. 3'ясовано, що 43\% опитаних мають високий рівень IT, 43\% мають вище середнього рівень IT, 14\% опитаних має середній рівень індексу тривожності (див. рис. 4.).

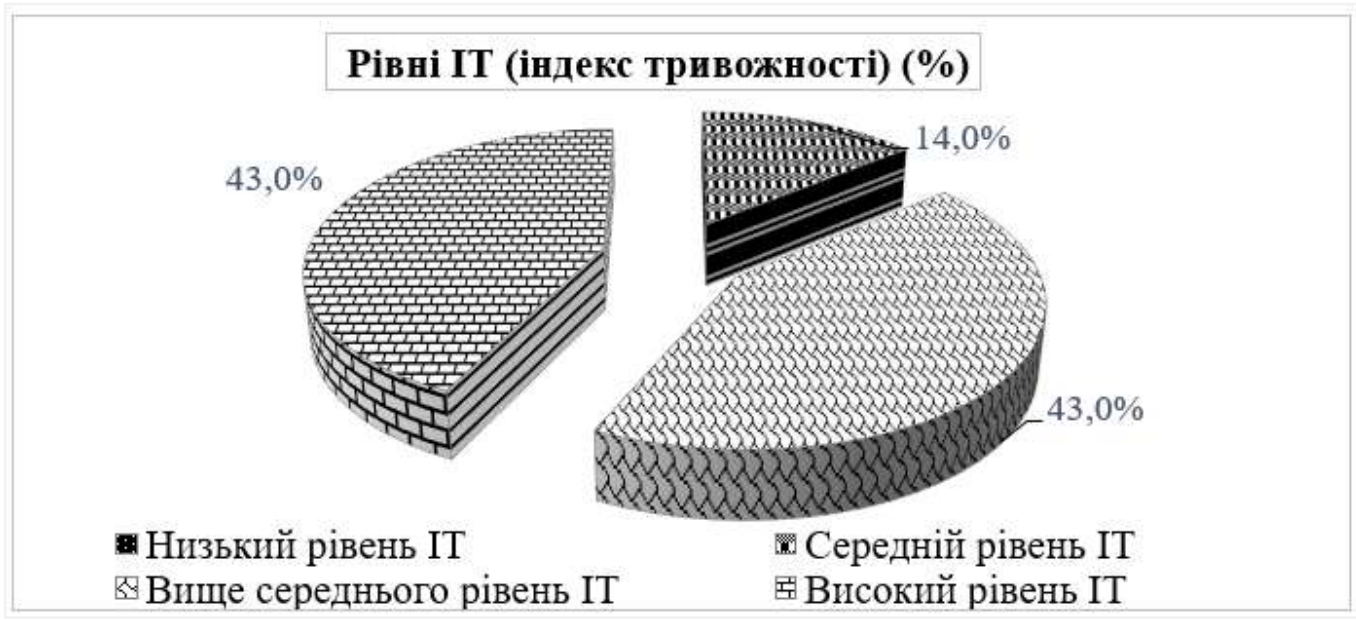

Pис. 4. Рівні індексу тривожності респондентів (\%) 
Окрему увагу ми звернули на якісний аналіз висловлювань дітей в момент обирання обличчя для малюнків. По-перше, ми фіксували ХВД (характер висловлювань дитини) з точки зору чіткості, нечіткості висловлювань, або повної відмови від висловлювань. Зафіксовано наступний ХВД (характер висловлювань дітей): високий рівень чіткості відповідей $-14 \%$; чіткі відповіді достатньо високого рівня чіткості - 14\%; переважна більшість дітей, а саме $71 \%$ продемонстрували середній, вище середнього рівні чіткості відповідей.

Зауважимо, що під чіткістю висловлювань ми розуміємо здатність дитини словом передати позитивну або негативну атмосферу малюнку й виразу обличчя. Враховуючи, що респондентами $є$ діти із порушеннями мовлення, критерій «чіткість висловлювання» на нашу думку, слід сприймати саме так. Для якісного аналізу нас цікавила кількість негативних виборів, тобто вибори СО (сумне обличчя). Ми порівняли кількість виборів веселих й сумних обличь, які зробила кожна дитина й з'ясували, що переважає вибір ВО - 29\%; вибір СО - 42\%; пропорційний вибір ВО/СО зробили 29\% опитаних.

Проаналізувавши висловлювання дітей, ми визначили їх емоційний досвід спілкування. Емоційний досвід спілкування визначався за загальним негативним або позитивний емоційним тоном висловлювання дитини. Ми встановили наявність як емоційно-позитивних, так й емоційно-негативних висловлювань.

На окрему увагу заслуговує факт наявності емоційно нейтральних висловлювань. Ми з'ясували, що емоційний характер висловлювань дітей дуже відрізнявся, а саме: емоційно-позитивні відповіді відсутні; емоційно-негативні відповіді переважали у 57\% респондентів; емоційно-нейтральні відповіді переважали у 14\%; нейтрально-пропорційні емоційно-позитивні й емоційнонегативні висловлювання - 29 \% опитаних дітей.

Висновки. Отже, емпіричне дослідження дозволило встановити наявність таких специфічних симптомів дезадаптивної поведінки дітей молодшого шкільного віку із порушеннями мовлення, як агресивна й конформно-агресивна поведінка при переважно середньому рівні комунікативної толерантності, середньому рівні прояву агресивної поведінки та помірно-захисної агресивності.

За результатами діагностики батькам 57\% респондентів рекомендовано звернутись до психолога, адже їх діти потребують термінової кваліфікованої психолого-педагогічної допомоги. На особливу увагу заслуговують 43\% респондентів, які за результатами діагностування потрапили до «групи ризику», а отже потребують термінової корекційної роботи. На окрему увагу батьків й викладачів заслуговує факт переважання у дітей негативного емоційного досвіду спілкування й діяльності. Перспективу роботи вбачаємо у продовженні емпіричних досліджень проявів дезадаптивної поведінки дітей молодшого шкільного віку із мовленнєвими порушеннями. 


\section{Лimepamypa:}

1. Матющенко I. M (2012). До проблеми соціалізації дітей з тяжкими порушеннями мовлення. Логопедія. 2012. №2. С. 53-56.

2. Ніколаєв Л. О., Маркелова А. В. (2019). Психологічні чинники дезадаптації дітей молодшого шкільного віку. Правничий вісник Університету «КРОК», №34. С. 125-134.

3. Осауленко Л. А. (2014). Формування моральної поведінки учнів з вадами розвитку: методичний посібник. Золотоноша, 2014. $100 \mathrm{c}$.

4. Рібцун Ю. (2019). Стандартизація початкової освіти дітей із тяжкими порушеннями мовлення в умовах Нової української школи. Науковий збірник «Актуальні питання гуманітарних наук: міжвузівський збірник наукових праць молодих вчених Дрогобицького державного педагогічного університету імені Івана Франка». Том 3, №23. С. 139-145.

5. Фирсанова Е. Ю. (2009). Изучение особенностей адаптации к школе у детей с нарушениями речи. Психологическая наука и образование. Электронный журнал, №3.

URL: http://psyedu.ru/files/articles/1366/pdf_version.pdf

6. Щербакова I. М., Харченко Т. Г. (2021). Поведінка дітей молодшого шкільного віку iз мовленнєвими порушеннями. Наукові перспективи: журнал. №11(17). С. 401-411. https://doi.org/10.52058/2708-7530-2021-11(17)-401-411

\section{References:}

1. Maksymenko, S. (2019). Teoriia rozvytku povedinky liudyny P. P. Blonskoho [The theory of human behavior development PP Blonsky]. Zbirnyk naukovykh prats «Problemy suchasnoi psykholohii» (29). 2015. S. 7-18. [in Ukrainian].

2. Nikolaiev, L .O., Markelova, A. V. (2019). Psykholohichni chynnyky dezadaptatsii ditei molodshoho shkilnoho viku [Psychological factors of maladaptation of children of primary school age]. Pravnychyi visnyk Universytetu «KROK», №34. S. 125-134. [in Ukrainian].

3. Osaulenko, L. A.(2014). Formuvannia moralnoi povedinky uchniv z vadamy rozvytku: metodychnyi posibnyk [Formation of moral behavior of students with developmental disabilities: a manual]. Zolotonosha. 2014. 100 s. [in Ukrainian].

4. Ribtsun, Yu. Standartyzatsiia pochatkovoi osvity ditei iz tiazhkymy porushenniamy movlennia v umovakh Novoi ukrainskoi shkoly [Standardization of primary education of children with severe speech disorders in the New Ukrainian school]. Naukovyi zbirnyk «Aktualni pytannia humanitarnykh nauk: mizhvuzivskyi zbirnyk naukovykh prats molodykh vchenykh Drohobytskoho derzhavnoho pedahohichnoho universytetu imeni Ivana Franka». Tom 3, №23. S. 139-145. [in Ukrainian].

5. Fyrsanova, E. Iu. (2009). Yzuchenye osobennostei adaptatsyy $k$ shkole $u$ detei $s$ narushenyiamy rechy [Study of the peculiarities of adaptation to school in children with speech disorders]. Psykholohycheskaia nauka y obrazovanye. Эlektronnыi zhurnal, №3. [in Russian].

URL: http://psyedu.ru/files/articles/1366/pdf_version.pdf

6. Shcherbakova, I. M., Kharchenko, T. H. (2021). Povedinka ditei molodshoho shkilnoho viku iz movlennievymy porushenniamy [Behaviour of children of primary school age with speech disorders]. Naukovi perspektyvy: zhurnal. № 11 (17). S. 401-411. https://doi.org/10.52058/27087530-2021-11(17)-401-411. [in Ukrainian]. 